\title{
Magnetic Anisotropy and the Paleosecular Variation Record in Stalagmites from Njirak Cave, East Java: The Effect of Detrital Magnetite Emplaced in Small Cavities by Flooding Events
}

\author{
Satria Bijaksana ${ }^{1)}$, Siti Zulaikah ${ }^{2)}$, and Joseph Paul Hodych ${ }^{3)}$ \\ ${ }^{1)}$ Faculty of Mathematics and Natural Sciences, \\ Institut Teknologi Bandung \\ ${ }^{2)}$ Department of Physics, State University of Jakarta \\ ${ }^{3)}$ Department of Earth Sciences, Memorial University of Newfoundland \\ St. John's, Newfoundland, A1B 3X5, Canada \\ e-mail: satria@fi.itb.ac.id
}

\begin{abstract}
Magnetic anisotropy and remanence were measured for 33 samples from the axis of two stalagmites from Njirak Cave in East Java. All 33 samples were stepwise demagnetized with alternating fields, but only 16 were stable enough to yield reliable characteristic remanence directions. These directions differ, especially in declination, from the present Earth's field direction and agree for samples of about the same age from both stalagmites, suggesting that the Earth's field at Njirak Cave maintained a declination averaging $23^{\circ}$ and an inclination averaging $-23^{\circ}$ for most of the past 2,500 years. Anisotropy of magnetic susceptibility is high, averaging 5.8\%. The minimum susceptibility axes are nearly horizontal with scattered declinations; whereas the maximum susceptibility axes tend to be steeply inclined (average inclination is 51\%). This implies that the long axes of the mainly multi-domain magnetite grains tend to be steeply inclined (rather than horizontal, as expected if the magnetite were in horizontal detrital layers). We suggest that this is due to the magnetite being in flood-emplaced detritus adhering to the steeply-inclined sides of small (2 to $5 \mathrm{~mm}$ ) cavities that cut across and are sealed off by the stalagmites' horizontal calcite growth layers. Steeply inclined maximum susceptibility axes should help detect such stalagmites, whose quality of paleosecular variation record may be lowered by magnetite-bearing cavities.
\end{abstract}

Keywords: Magnetic anisotropy, Paleomagnetism, Paleosecular variation, Stalagmites, Speleothems

\section{Introduction}

Earlier paleomagnetic studies ${ }^{1-9)}$ have shown that speleothems, especially stalagmites, may reliably record paleosecular variation of the Earth's magnetic field. These cave deposits consist mostly of calcite and usually have relatively weak magnetic remanence carried by detrital magnetite ${ }^{5)}$. Most of the previously studied stalagmites are several thousand years old, although one is at least 780 thousand years old ${ }^{6}$.

This paper describes our magnetic study of stalagmites from East Java, Indonesia and seems to be the first paper to study the magnetic anisotropy of stalagmites. Paleomagnetic samples with magnetic anisotropy of more than five percent may record the Earth's magnetic field direction erroneously and should be treated cautiously ${ }^{10)}$. Stalagmites are usually deposited on the cave floor as successive inverted bowl-shaped growth layers with the magnetite in thin layers of detritus between growth layers ${ }^{5}$. Hence, along the axis of the stalagmite, the magnetic anisotropy should be similar to that of other magnetite-bearing sediments deposited in horizontal layers. That is, the axis of minimum susceptibility should be perpendicular to the bedding plane and if the anisotropy is $>5 \%$, remanence can be of significantly shallower inclination than the field in which it was acquired. In such a case, magnetic anisotropy warns of paleomagnetic inclination shallowing and may help correct for it ${ }^{11-13)}$.
Our stalagmites from Njirak cave do preserve a paleosecular variation record but it is not of high quality with only 16 of 33 samples carrying stable remanence. Susceptibility anisotropy is large enough to cause significant paleomagnetic inclination error, but surprisingly, the minimum susceptibility axis is found to be parallel rather than perpendicular to bedding. Therefore, we focus on understanding how the magnetic anisotropy and remanence were acquired in these stalagmites.

\section{Samples and their Preparation}

Two stalagmites (B and K) were collected from Njirak cave in the regency of Trenggalek, East Java ( $8^{\circ} 13^{\prime} \mathrm{S} 111^{\circ} 45^{\prime} \mathrm{W}$; see Figure 1) in September 1998. The cave is located in a karst region hosted by the Early Miocene Campurdarat Formation of crystallized limestone with intercalation of carbonaceous claystone $^{14)}$. The stalagmites were taken about $400 \mathrm{~m}$ from the entrance of an intricate unmapped cave system from what can be classified as an interior chamber ${ }^{15)}$ although it has been subjected to flooding. Stalagmites in this chamber are expected to be nonporous and to contain no detritus unless flooded. Stalagmites $\mathrm{B}$ and $\mathrm{K}$ are 84 and $54 \mathrm{~cm}$ high respectively. Prior to removing them from the cave, the stalagmites were enclosed in plaster of Paris upon which the orientation was marked. 


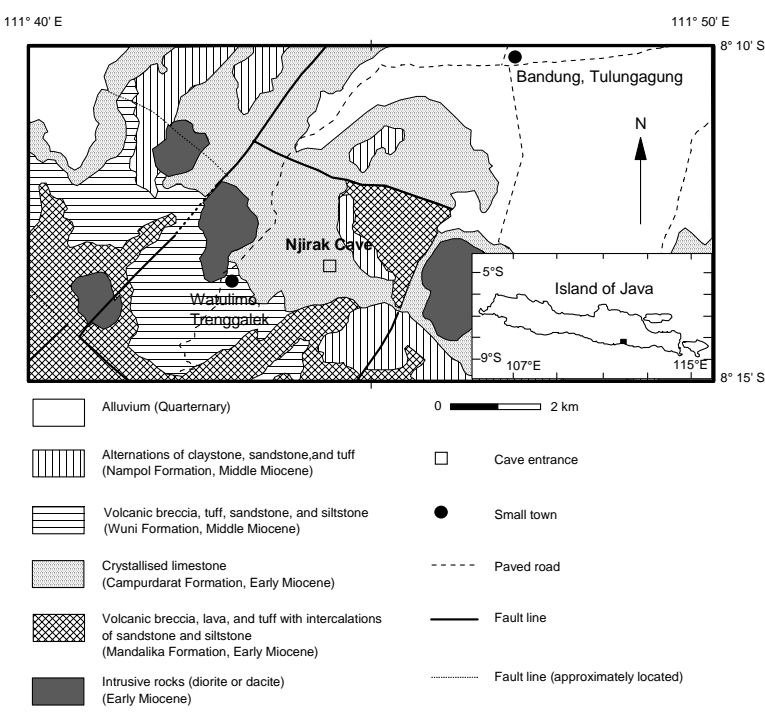

Figure 1. Map showing the location of Njirak Cave, East Java $^{14)}$.

In the laboratory, each stalagmite was cut in half vertically by a diamond saw. One half of each stalagmite was used for sampling and is termed the working half, while the other half is preserved as an archive. The stalagmites are made mostly of calcite as was shown by X-ray diffraction ${ }^{16)}$. Inverted bowlshaped growth layers of different coloration are clearly visible in each cross-section (Figure 2). Most layers are white to gray in color while some are brown to black. Small cavities containing detritus are also visible in some layers.

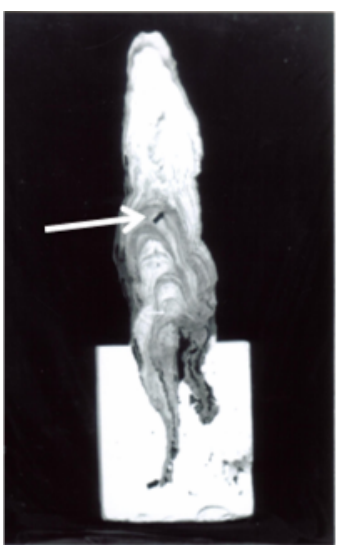

B

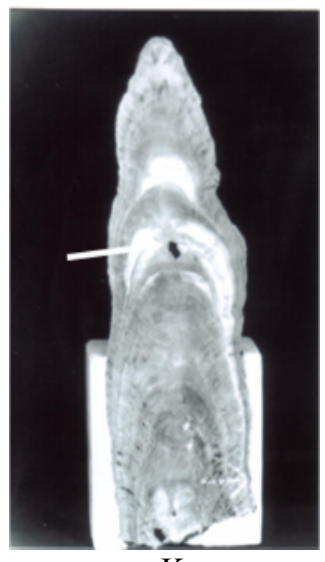

$\mathrm{K}$
Figure 2. Photographs of stalagmites $\mathrm{B}$ and $\mathrm{K}$ with arrows indicating locations of calcite samples that yielded ${ }^{14} \mathrm{C}$ dates.

Carbon-14 dating ${ }^{17)}$ using chips of calcite from the bottom of each stalagmite (shown by the lowermost arrows in Figure 2) yielded calibrated absolute ages of 2,893 \pm 238 years for stalagmite $\mathrm{K}$ and $3,356 \pm 272$ years for stalagmite B. Chips of calcite from higher in each stalagmite (shown by the upper arrows in Figure 2) yielded ages of 2,337 \pm 270 years for stalagmite $K$ and $2,426 \pm 295$ years for stalagmite B. The errors quoted are $\pm 1 \sigma^{18)}$. The lower part of both stalagmites (between the arrows in Figure 2) grew at the same average rate of $0.58 \mathrm{~mm} /$ year. The upper part of both stalagmites (above the uppermost arrows of Figure 2) grew at the significantly lower average rate of $0.12 \mathrm{~mm} /$ year. (Both stalagmites were still growing when collected.)

Each working half was then sliced horizontally into semicircular plates of $3.0 \mathrm{~cm}$ thickness. Each plate was numbered starting with K-1 and B-1 for the topmost plates followed by larger numbers for the successive lower plates. Samples were obtained by drilling a vertical core of $2.5 \mathrm{~cm}$ diameter from each plate near the axis of the stalagmite. (Plates from the lowest part of stalagmite B were not large enough for coring). Each sample was then trimmed to $2.2 \mathrm{~cm}$ length to fit the measuring instruments. This sample size is comparable to that used in some previous studies of stalagmite remanence ${ }^{5-6,8-9)}$ but is larger than in some others ${ }^{2,4)}$. Samples 1 to 9 in each stalagmite should each represent -183 years of deposition and samples 10 to 17 should each represent -38 years of deposition. (The appropriate age of each sample can be obtained from the scale at the right hand edge of Figure 8). Each sample is of a size and shape suitable for magnetic anisotropy measurement.

\section{Methods and Results}

Prior to measurement of magnetic remanence, AMS (anisotropy of magnetic susceptibility) was measured using a Kappabridge KLY-2 susceptibility meter (AGICO, Brno, Czech Republic). Magnetic susceptibility of each sample was measured along 13 directions ${ }^{19)}$ using a weak magnetic field (300 A/m) with a frequency of $920 \mathrm{~Hz}$. The anisotropy was treated as a second-rank tensor represented by the susceptibility magnitudes $\left(\chi_{\max }, \chi_{\text {int }}\right.$, and $\left.\chi_{\min }\right)$ along the maximum, intermediate, and minimum principal axes. The average susceptibility, $\chi_{\mathrm{avg}}$, is defined as $\left(\chi_{\max }+\right.$ $\left.\chi_{\text {int }}+\chi_{\text {min }}\right) / 3$ and the percent anisotropy, $h$, is defined ${ }^{20)}$ as $\left\{\left(\chi_{\max }-\chi_{\text {min }}\right) / \chi_{\text {int }}\right\} \times 100 \%$. The shape of the anisotropy ellipsoid is represented by the shape parameter, $T$, which is defined ${ }^{21)}$ as $\left\{2\left(\eta_{2}-\eta_{3}\right) /\left(\eta_{1}-\right.\right.$ $\left.\left.\eta_{3}\right)\right\}-1$, where $\eta_{1}=\ln \chi_{\max }, \eta_{2}=\ln \chi_{\text {int }}$, and $\eta_{3}=\ln$ $\chi_{\min }$. Negative $T$ indicates that the susceptibility ellipsoid is prolate (rod-like) in shape, whereas positive $T$ indicates oblate (disk-like) ellipsoids ${ }^{21-22}$ ). AMS results are listed in Table 1 and plotted in Figure 3.

Magnetic remanence was measured using a Minispin spinner magnetometer (Molspin Ltd., UK). All the samples were subjected to stepwise alternating field (AF) demagnetization using an AF demagnetizer (Molspin Ltd., UK) with peak field of up to $100 \mathrm{mT}$. Demagnetization was carried out in steps of $2.5 \mathrm{mT}$ until the remanence was reduced to about $10 \%$ of its original intensity or less. 
Table 1. Results of AMS (anisotropy of magnetic susceptibility) measurements

\begin{tabular}{|c|c|c|c|c|c|c|c|c|c|}
\hline Sample \# & $\begin{array}{c}\chi_{\min } \\
\left(10^{-6}\right)\end{array}$ & $\begin{array}{c}\chi_{\text {int }} \\
\left(10^{-6}\right) \\
\end{array}$ & $\begin{array}{c}\chi_{\max } \\
\left(10^{-6}\right)\end{array}$ & $\begin{array}{c}\mathrm{D}_{\min } \\
\left(^{\circ}\right)\end{array}$ & $\begin{array}{c}\mathrm{I}_{\min } \\
\left({ }^{\circ}\right)\end{array}$ & $\begin{array}{c}\mathrm{D}_{\max } \\
\left({ }^{\circ}\right) \\
\end{array}$ & $\begin{array}{c}\mathrm{I}_{\max } \\
\left({ }^{\circ}\right) \\
\end{array}$ & $\begin{array}{c}h \\
(\%) \\
\end{array}$ & $T$ \\
\hline K1 & 4573 & 4721 & 4890 & 15.2 & 3.1 & 75.6 & 83.6 & 6.7 & -0.055 \\
\hline K2 & 2588 & 2683 & 2814 & 87.4 & 4.5 & 341.0 & 74.5 & 8.4 & -0.013 \\
\hline K3 & 4008 & 4066 & 4143 & 338.4 & 15.0 & 76.3 & 27.1 & 3.3 & -0.134 \\
\hline K4 & 5585 & 5950 & 6328 & 233.4 & 12.2 & 348.1 & 63.5 & 12.5 & 0.012 \\
\hline K5 & 563 & 576 & 592 & 320.5 & 3.0 & 57.4 & 66.8 & 5.0 & -0.128 \\
\hline K6 & 258 & 261 & 270 & 276.0 & 5.9 & 0.0 & 45.0 & 4.6 & -0.431 \\
\hline K7 & 1170 & 1194 & 1250 & 93.5 & 0.4 & 4.6 & 71.5 & 6.7 & -0.362 \\
\hline K8 & 441 & 444 & 469 & 195.8 & 33.6 & 307.7 & 29.3 & 6.3 & -0.757 \\
\hline K9 & 1066 & 1091 & 1112 & 253.4 & 8.0 & 354.4 & 69.7 & 4.2 & 0.096 \\
\hline K10 & 3040 & 3150 & 3384 & 123.8 & 26.5 & 358.4 & 49.2 & 10.9 & -0.338 \\
\hline K11 & 1204 & 1238 & 1308 & 321.4 & 3.7 & 67.2 & 76.7 & 8.4 & -0.337 \\
\hline K12 & 3841 & 3953 & 4054 & 285.7 & 9.5 & 34.8 & 62.9 & 5.4 & 0.070 \\
\hline K13 & 3794 & 3922 & 4141 & 275.1 & 15.3 & 26.3 & 52.9 & 8.8 & -0.244 \\
\hline K14 & 2683 & 2767 & 2825 & 39.1 & 28.5 & 116.9 & 21.4 & 5.1 & 0.188 \\
\hline K15 & 2413 & 2442 & 2504 & 287.7 & 21.5 & 33.6 & 35.0 & 3.7 & -0.350 \\
\hline K16 & 2765 & 2896 & 2966 & 224.0 & 5.1 & 311.7 & 23.9 & 6.9 & 0.318 \\
\hline K17 & 1803 & 1825 & 1839 & 89.4 & 33.4 & 166.5 & 18.7 & 2.0 & 0.207 \\
\hline B2 & 870 & 909 & 925 & 266.6 & 6.1 & 359.9 & 28.4 & 6.1 & 0.423 \\
\hline B3 & 1274 & 1361 & 1392 & 124.1 & 0.9 & 29.6 & 78.5 & 8.7 & 0.488 \\
\hline B4 & 1478 & 1503 & 1532 & 277.1 & 7.0 & 41.1 & 77.7 & 3.6 & -0.071 \\
\hline B5 & 517 & 548 & 552 & 165.2 & 15.5 & 66.7 & 28.2 & 6.4 & 0.755 \\
\hline B6 & 147 & 151 & 162 & 19.9 & 11.1 & 286.6 & 16.6 & 9.9 & -0.371 \\
\hline B7 & 302 & 307 & 313 & 45.0 & 0.0 & 315.0 & 38.9 & 3.6 & -0.049 \\
\hline B8 & 219 & 231 & 233 & 178.7 & 24.5 & 101.9 & 26.7 & 6.1 & 0.677 \\
\hline B9 & 576 & 605 & 614 & 335.2 & 3.9 & 64.4 & 11.6 & 6.3 & 0.499 \\
\hline B10 & 1767 & 1801 & 1816 & 53.7 & 6.6 & 314.1 & 52.1 & 2.7 & 0.420 \\
\hline B11 & 1457 & 1517 & 1517 & 270.0 & 0.0 & 0.0 & 90.0 & 4.0 & 1.000 \\
\hline B12 & 2290 & 2403 & 2417 & 89.2 & 1.9 & 348.5 & 79.8 & 5.3 & 0.794 \\
\hline B13 & 3557 & 3763 & 3776 & 247.6 & 2.3 & 17.9 & 86.4 & 5.8 & 0.883 \\
\hline B14 & 2547 & 2601 & 2629 & 298.5 & 9.4 & 50.3 & 66.0 & 3.2 & 0.319 \\
\hline B15 & 777 & 782 & 793 & 240.3 & 9.8 & 327.1 & 17.8 & 2.0 & -0.320 \\
\hline B16 & 871 & 904 & 923 & 102.7 & 8.9 & 2.3 & 48.9 & 5.8 & 0.266 \\
\hline B17 & 1253 & 1271 & 1296 & 22.2 & 3.4 & 288.3 & 48.9 & 3.4 & -0.077 \\
\hline
\end{tabular}

$\chi_{\min }, \chi_{\text {int }}$, and $\chi_{\max }$ are susceptibilities (in SI) along the three principle axes of the susceptibility ellipsoid. $D_{\min }$ and $I_{\min }$ are the declination and inclination of the minimum susceptibility axis. $D_{\max }$ and $I_{\max }$ are the declination and inclination of the maximum susceptibility axis. Percent anisotropy $h=\left\{\left(\chi_{\max }-\chi_{\min }\right) / \chi_{\text {int }}\right\} \times 100 \%$. Shape parameter $T$ is negative for prolate and positive for oblate susceptibility ellipsoids.

Table 2 lists the intensity, declination, and inclination of NRM (natural remanence, before demagnetization). The remanence is strong but often of low coercivity and unstable on AF demagnetization. The median destructive field (MDF), which is the peak alternating field required to reduce the NRM intensity by half, is on average only $4.0 \mathrm{mT}$ (Table 2). Figure 4 shows intensity decay curves and vector plots for three representative samples. Sample K-14 (Figure 4a) is the most stable of the samples while sample K-13 (Figure $4 \mathrm{~b}$ ) represents a more typical stable sample. Sample B-5 (Figure 4c) represents a sample that is unstable.
The characteristic magnetization direction yielded by stepwise AF demagnetization of each sample was determined using a computer program for principal component analysis ${ }^{23)}$. The maximum angular deviation (MAD) was also determined giving a quantitative measure of the precision of the leastsquares-fit line (not forced through the origin) ${ }^{10)}$. Only 16 samples whose MAD value does not exceed $15^{\circ}$ are considered reliable and have their characteristic directions listed in Table 2 along with the range of alternating fields used for the leastsquares fitting. We have excluded the NRM value from this analysis to avoid biasing by very low coercivity $(0-2.5 \mathrm{mT})$ magnetite. 
Table 2. Results of remanence measurements

\begin{tabular}{|c|c|c|c|c|c|c|c|}
\hline Sample \# & $\begin{array}{c}\mathrm{NRM} \\
\text { Intensity } \\
(\mathrm{mA} / \mathrm{m}) \\
\end{array}$ & $\begin{array}{c}\text { NRM } \\
\text { Declination } \\
\left({ }^{\circ}\right) \\
\end{array}$ & $\begin{array}{c}\text { NRM } \\
\text { Inclination } \\
\left({ }^{\circ}\right) \\
\end{array}$ & $\begin{array}{l}\text { MDF } \\
(\mathrm{mT})\end{array}$ & $\begin{array}{c}\text { Characteristic } \\
\text { Declination } \\
\left({ }^{\circ}\right) \\
\end{array}$ & $\begin{array}{c}\text { Characteristic } \\
\text { Inclination } \\
\left({ }^{\circ}\right) \\
\end{array}$ & $\begin{array}{c}\text { AF } \\
\text { Range } \\
(\mathrm{mT}) \\
\end{array}$ \\
\hline K1 & 30.46 & 24.0 & -43.8 & 13.7 & 28.2 & -36.7 & $2.5-20$ \\
\hline $\mathrm{K} 2$ & 13.73 & 6.4 & -42.4 & 3.5 & NR & NR & - \\
\hline $\mathrm{K} 3$ & 24.36 & 27.5 & -40.5 & 1.8 & NR & NR & - \\
\hline K4 & 28.51 & 36.4 & -33.4 & 1.5 & 16.6 & -36.4 & $2.5-17.5$ \\
\hline K5 & 9.03 & 36.9 & -32.1 & 1.4 & NR & NR & - \\
\hline K6 & 2.39 & 19.7 & -39.6 & 2.0 & NR & NR & - \\
\hline K7 & 13.22 & 28.7 & -43.9 & 2.0 & NR & NR & - \\
\hline K8 & 4.19 & 12.8 & -27.7 & 1.3 & NR & NR & - \\
\hline K9 & 7.55 & 15.2 & -14.1 & 1.5 & NR & NR & - \\
\hline K10 & 23.81 & 34.5 & -43.1 & 5.5 & NR & NR & - \\
\hline K11 & 11.54 & 31.9 & -23.3 & 1.5 & 37.8 & -28.1 & $2.5-10$ \\
\hline K12 & 25.31 & 28.6 & -29.4 & 2.0 & NR & NR & - \\
\hline K13 & 36.52 & 29.8 & -23.6 & 2.5 & 16.1 & -13.3 & $2.5-20$ \\
\hline K14 & 46.31 & 29.3 & -13.7 & 16.3 & 26.4 & -7.5 & $5-40$ \\
\hline K15 & 56.42 & 29.6 & -20.1 & 13.8 & 31.4 & -18.3 & $2.5-25$ \\
\hline K16 & 149.30 & 21.3 & -1.1 & 1.8 & 31.8 & -7.9 & $7.5-40$ \\
\hline K17 & 44.07 & 62.9 & -28.3 & 1.5 & NR & NR & - \\
\hline B2 & 10.37 & 22.7 & -41.9 & 13.5 & 8.4 & -20.0 & $25-32.5$ \\
\hline B3 & 15.35 & 15.2 & -27.1 & 1.7 & NR & NR & - \\
\hline B4 & 16.41 & 4.1 & -35.8 & 2.0 & NR & NR & - \\
\hline B5 & 8.49 & 3.3 & -12.4 & 2.5 & NR & NR & - \\
\hline B6 & 4.64 & 32.2 & -27.0 & 2.5 & 32.6 & -27.8 & $2.5-12.5$ \\
\hline B7 & 7.55 & 20.4 & -34.8 & 5.5 & NR & NR & - \\
\hline B8 & 6.99 & 26.5 & -19.3 & 2.4 & 13.3 & -18.6 & $2.5-17.5$ \\
\hline B9 & 4.73 & 38.3 & -46.7 & 9.5 & NR & NR & - \\
\hline B10 & 22.83 & 32.2 & -23.2 & 2.0 & 23.6 & -25.7 & $2.5-17.5$ \\
\hline B11 & 21.44 & 23.8 & -24.3 & 2.5 & 16.4 & -10.0 & $2.5-27.5$ \\
\hline B12 & 29.39 & 26.8 & -29.4 & 3.0 & 27.4 & -24.7 & $2.5-25$ \\
\hline B13 & 49.43 & 25.2 & -32.0 & 1.8 & 22.7 & -21.8 & $2.5-27.5$ \\
\hline B14 & 64.42 & 36.3 & -30.2 & 2.0 & 19.7 & -24.8 & $2.5-25$ \\
\hline B15 & 13.72 & 34.7 & -33.9 & 3.1 & NR & NR & - \\
\hline B16 & 9.35 & 8.3 & -47.6 & 2.5 & 17.9 & -40.7 & $2.5-12.5$ \\
\hline B17 & 9.64 & 18.6 & -42.1 & 2.5 & NR & NR & - \\
\hline
\end{tabular}

MDF is the median destructive field. NR indicates that the direction of the characteristic magnetization in the sample cannot be determined reliably as the maximum angular deviation exceeds $15 \mathrm{E}$. The last column indicates the AF range that yielded the characteristic direction.

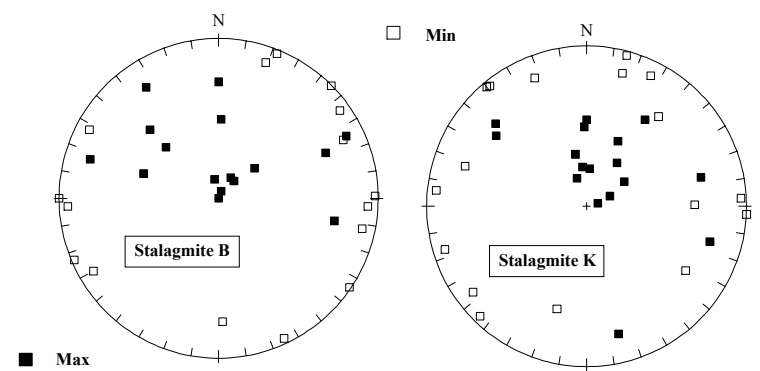

Figure 3. Equal area projections of directions of maximum (solid cubes) and minimum (hollow cubes) principal susceptibility axes for the samples from stalagmites B and $\mathrm{K}$.

\section{Discussion}

\section{1 Magnetic minerals}

Both the high magnetic susceptibility and the strong remanence that is easily AF demagnetized suggest that magnetite is the dominant magnetic mineral in our stalagmite samples. The low coercivity of remanence in most samples (Figure 4b) suggests that the magnetite is mostly in coarse multi-domain grains. Curves of isothermal remanent magnetization (IRM) acquisition in increasing magnetic fields were measured for several samples and also suggest the dominance of multi-domain magnetite (Figure 5). 


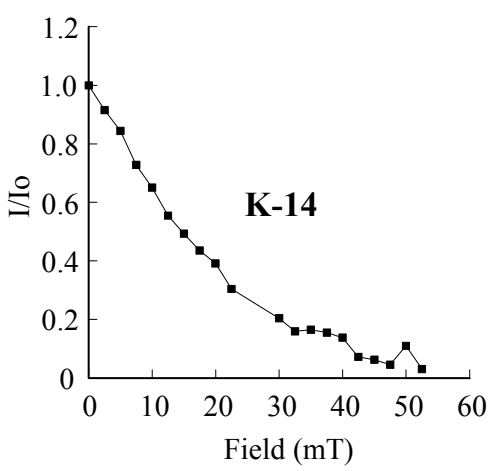

a

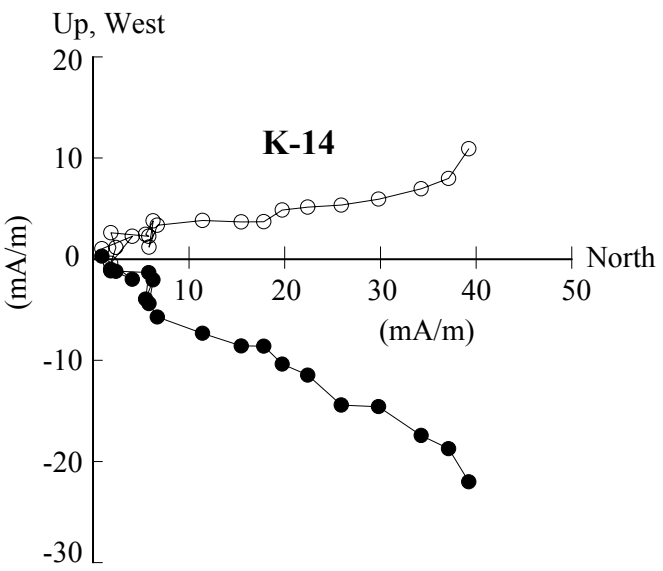

Down, East

Up, West
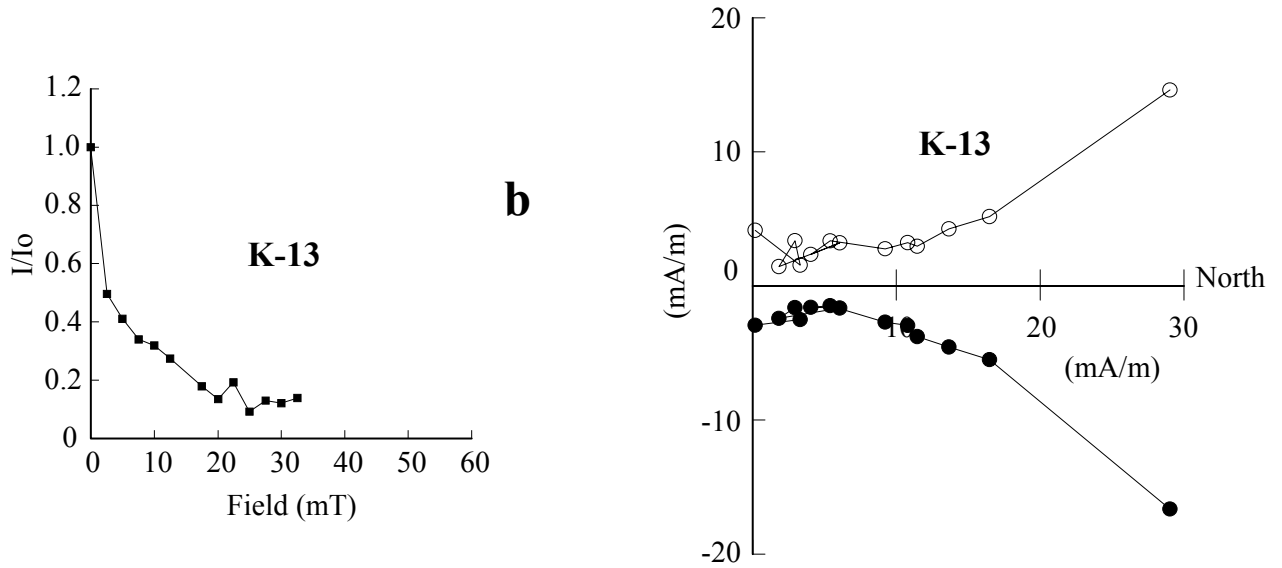

Down, East
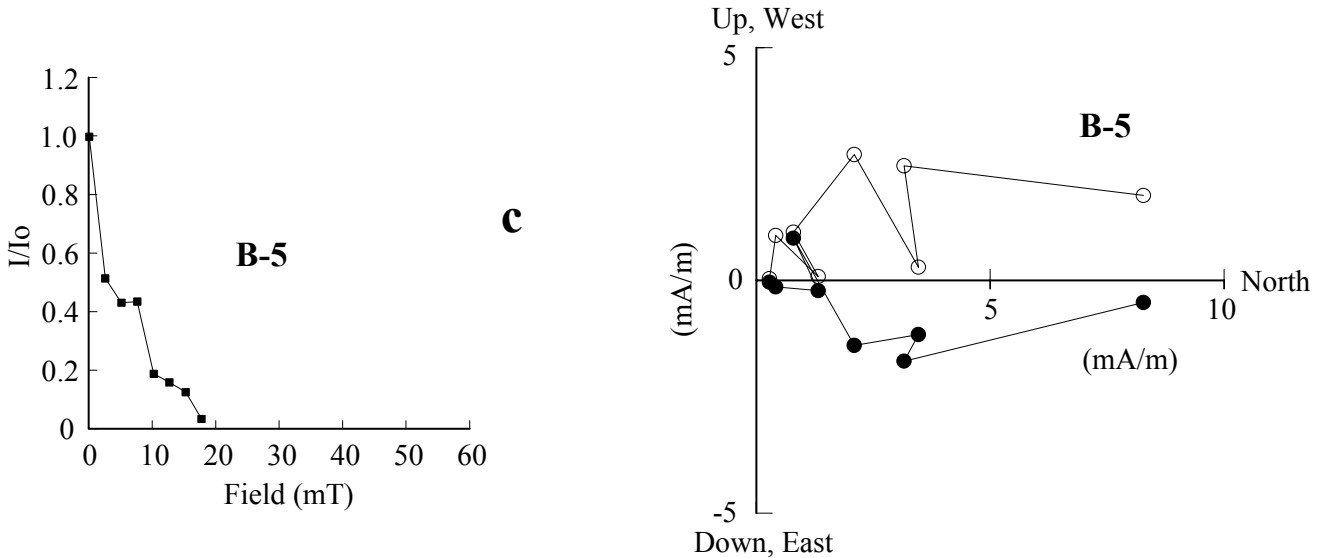

Figure 4. Intensity decay curves and plots of progressive AF demagnetization for (a) K-14, the most stable sample, (b) K-13 a typical stable sample, and (c) B5 an unstable sample. Solid circles represent projection onto the horizontal plane, while hollow circles represent projection onto the vertical plane.

For multi-domain magnetite grains, the susceptibility depends strongly on the shape of the grains. Assuming that the magnetite grains in stalagmite samples are roughly equidimensional, the volumetric fraction of magnetite can be estimated as the volumetric susceptibility divided by $3^{23}$. The susceptibility averages $1,280 \times 10^{-6}$ (SI) for stalagmite $\mathrm{B}$ samples and $2,546 \times 10^{-6}(\mathrm{SI})$ for stalagmite $\mathrm{K}$ samples. This implies a volumetric magnetite content averaging $-0.04 \%$ for stalagmite $\mathrm{B}$ samples and $-0.08 \%$ for stalagmite $\mathrm{K}$ samples. 


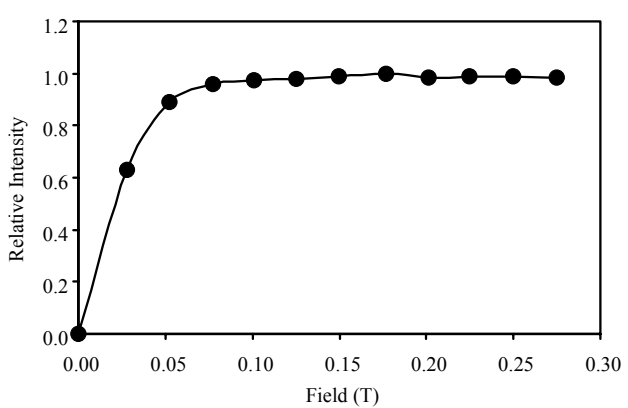

Figure 5. Normalized curve for IRM acquisition of representative sample B14.

What appear to be coarse magnetite grains can be seen with a hand lens in detritus that lines small (2$5 \mathrm{~mm}$ ) cavities in the interior of the stalagmites. This detritus resembles the sandy silt that is presently on the floor of the cave and that was likely brought into the cave by flooding events. Presumably, floods swept the detritus into cavities on the surface of the stalagmites which were subsequently sealed off by calcite growth layers. Cavities are quite common in stalagmites ${ }^{24-25)}$ and such cavities are found on the present surface of our stalagmites and do contain detritus. Figure 6 shows an example of typical cavities found inside our stalagmites.

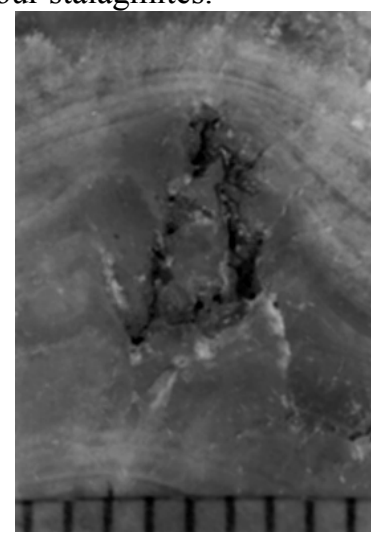

Figure 6. Photograph of a typical cavity found in the stalagmites. The cavity tends to be elongated perpendicular to the growth layers. The growth layers sealed off the cavity and its detritus content. Some of the detritus is cemented in place and some was washed away during polishing. The scale is indicated at the bottom of the photograph by stripes at millimeter intervals

To confirm the presence of coarse magnetite grains in the cavities, cavities about $3 \mathrm{~mm}$ in size were broken open for stalagmite sample K-17 and examined using a scanning electron microscope with an energydispersive X-ray analysis system. Figure 7 shows the backscattered and secondary electron images of in situ grains within one of the cavities. Brighter grains in backscattered electron images are often magnetite with a little titanium (on average $5 \%$ Ti by weight). Duller grains are often plagioclase. The composition and angular shape of both the magnetite and plagioclase grains support a detrital origin. Magnetite does occur in the sediment on the cave floor as was confirmed by extracting magnetic grains from the sediment, pulverizing them and using X-ray diffraction analysis.

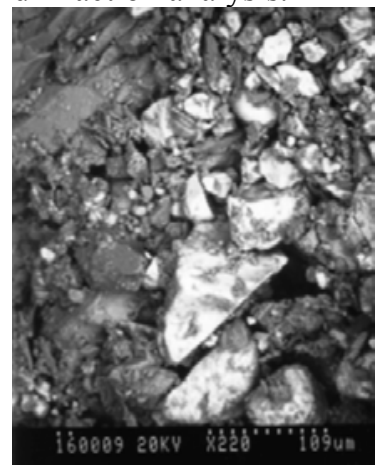

(a)

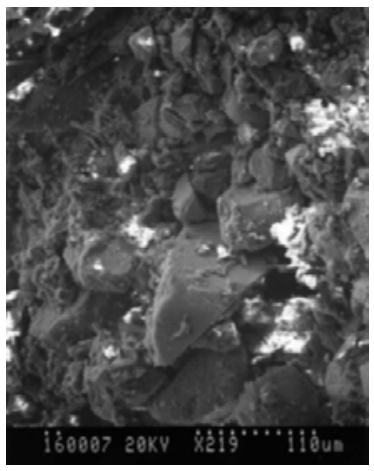

(b)
Figure 7. SEM micrographs of in situ grains in a cavity from stalagmite $\mathrm{K}$ in backscattered (a) and secondary (b) electron images. Energy-dispersive Xray analysis shows that the bright grains in (a) are magnetite with a small titanium content.

\section{2 Remanent magnetization}

The average NRM intensity of our stalagmite samples is similar to that of stalagmites from Papua New Guinea ${ }^{9)}$ but is up to two orders of magnitude higher than that reported for Mexican ${ }^{3)}$ or Chinese ${ }^{8)}$ stalagmites. As can be seen in Figure 8, the NRM intensity correlates with magnetic susceptibility (with $99 \%$ confidence, since the correlation coefficient is 0.456 for 33 samples). Magnetic susceptibility and hence NRM intensity should both be approximately proportional to magnetite content.

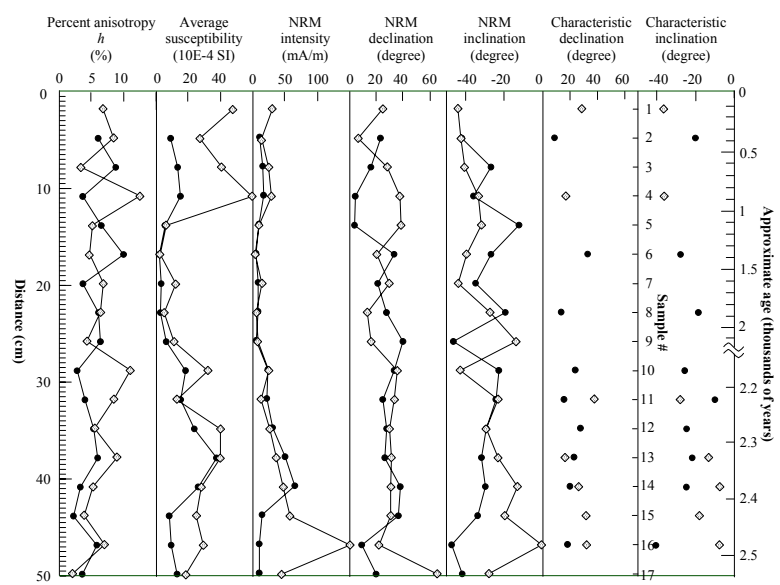

Figure 8. The percent susceptibility anisotropy, average magnetic susceptibility and the natural magnetic remanence (intensity, declination, and inclination) as a function of sample position from the top of the stalagmite. Solid circles indicate samples from stalagmite B and stippled diamonds indicate samples from stalagmite $\mathrm{K}$. 
It had been suggested (personal communication with A. Kosterov and S. Openshaw) that our stalagmite samples might have acquired their unstable NRM because of coring; that is, the rotating drill bit might have induced a magnetic remanence in the samples. To test this possibility, several new samples were prepared by cutting $2.4 \mathrm{~cm}$ cubes instead of by coring. The remanence measurements on the cubes showed that they behaved the same as their cylindrical counter-parts. Thus, coring was not the cause of the unstable NRM. The magnetic anisotropy of the cubes also did not significantly differ from that of the cores.

For both stalagmites, the declination of NRM (before demagnetization) is similar between samples 6 and 15 and shows little change with depth. The average declination of NRM for all 33 of the samples from the two stalagmites is $26^{\circ} \pm 4^{\circ}$ ( $2 \sigma$ of average) which differs significantly from the $1^{\circ}$ declination of the present Earth's field. This shows that, despite the low coercivity of most of the samples, they are not entirely viscously remagnetized along the present Earth's field direction, but must carry a more ancient remanence.

This ancient remanence is confirmed by the 16 out of 33 samples whose principal component analysis yields characteristic remenence with maximum angular deviation $\sim 15^{\circ}$ upon stepwise $\mathrm{AF}$ demagnetization. The average characteristic declinations for the two stalagmites do not significantly differ and averaging all 16 characteristic declinations yields $23^{\circ} \pm 4^{\circ}(2 \sigma$ of average $)$ which is significantly different from the $1^{\circ}$ declination of the present Earth's field. The average characteristic inclinations for the two stalagmites also do not significantly differ and averaging all characteristic inclinations yields $-23^{\circ} \pm 5^{\circ}(2 \sigma$ of average $)$ which is also significantly different from the $-35^{\circ}$ inclination of the present Earth's field. Furthermore, when samples of about the same age both yield characteristic directions, their inclinations and declinations do not significantly differ (with the exception of the inclinations of K16 and B16). Hence, it is very likely that the characteristic remanence directions do record paleosecular variation.

The paleosecular variation record for our two stalagmites is very incomplete. (A more complete record likely would have resulted if our $2.2 \mathrm{~cm}$ high cylindrical samples had been sliced into $-5 \mathrm{~mm}$ high disks after the anisotropy measurements but before AF demagnetization). Nevertheless, the record does suggest that the magnetic field declination at Njirak Cave did not vary greatly over much of the last 2500 years and that it averaged $-23^{\circ}$ east of north. For the same time period in northwest Australia, magnetic declination averaged $-30^{\circ}$ west of north with little variation as recorded by lake sediments ${ }^{26)}$. We suggest that these anomalous declinations may be due to the non-dipole field having had a local pole of attraction beneath the Philippines for much of the past 2500 years. (See Figure 9).

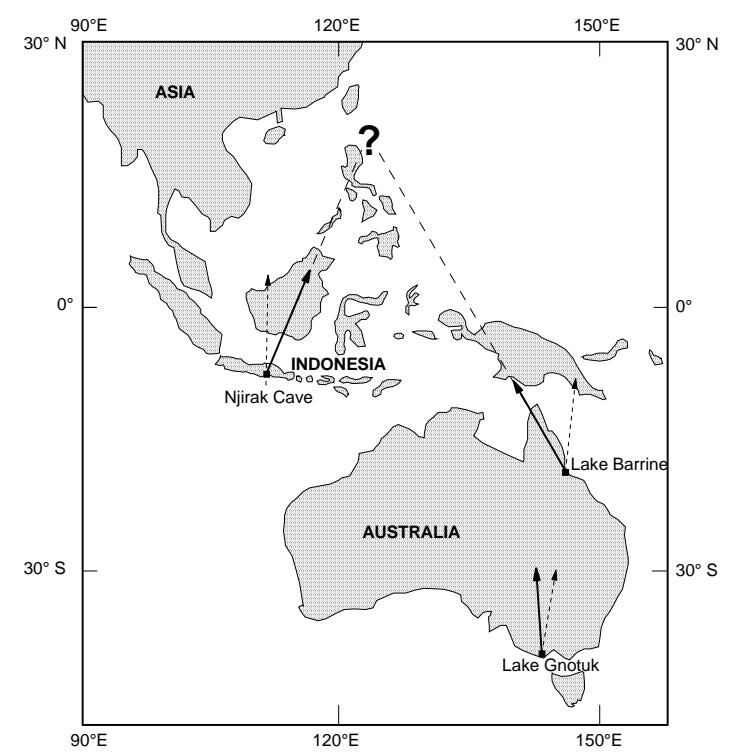

Figure 9. Map showing the locations of Njirak Cave in Java, and Lake Barrine and Lake Gnotuk in Australia. Dashed arrows show the present Earth's field declinations. Solid arrows show the declinations of the Earth's field recorded in the stalagmites and in the lake sediments averaged over the past 2500 years. A possible local pole of attraction of the non-dipole field is shown by a question mark near the Philippines.

\subsection{Susceptibility anisotropy}

Our samples are all drilled near the axis of the stalagmites, where growth layers are approximately horizontal. The magnetite grains are multi-domain and hence their long axes should be easiest to magnetize (susceptibility $\chi$ should be a maximum). We had expected that most of the magnetite in our samples would be in thin horizontal layers of detritus between calcite growth layers, as described by previous workers ${ }^{5)}$. Such magnetite grains should have their long $\left(\chi_{\max }\right)$ axes preferentially in the horizontal plane with random azimuth, producing an oblate magnetic anisotropy with the $\chi_{\min }$ axis vertical. Instead, all of our samples have their $\chi_{\min }$ axis close to horizontal while the $\chi_{\max }$ axis is often steeply inclined. This implies that the long axes of the magnetite grains tend to be steeply inclined. We suggest that this is due to most of the magnetite in our samples being in small detritus-lined cavities rather than in horizontal layers. As seen in Figure 6, these cavities are of irregular shape but tend to be elongated perpendicular to the growth layers (that is, elongated along the axis of preferred calcite crystal growth ${ }^{24)}$. We suggest that the magnetite grains adhering to the steeply dipping sides of the cavities tend to have their long $\left(\chi_{\max }\right)$ axes steeply dipping.

The susceptibility anisotropy in most of our samples exceeds the $5 \%$ at which paleomagnetists begin to question whether the samples have accurately recorded magnetic field directions. However, there is no obvious correlation between magnetization direction and anisotropy in our samples. The 
anisotropy might cause the remanence inclination to be a little steeper on average than the field inclination in which it was acquired, but the remanence declination should on average be unaffected, since the $\chi_{\max }$ axes are of random declination (Figure 3 ).

Finding high anisotropy ( $>5 \%)$ with steep inclination of $\chi_{\max }$ axes along the axis of a stalagmite should warn paleomagnetists that most of the magnetite is not in horizontal layers but may be in cavities that cut across growth lines. This can reduce the quality of the paleosecular variation record and may contribute to remanence instability since the magnetite grains in cavities may be coarser and looser than magnetite in horizontal layers.

\section{Conclusions}

The magnetic properties of the two stalagmites from Njirak cave in east Java are dominated by low coercivity magnetite that is likely multi-domain. Most of the magnetite appears to be in coarse, slightly titaniferous, angular grains among detritus lining small $(2-5 \mathrm{~mm})$ cavities within the calcite of the stalagmites. Flooding events likely placed the detritus into the cavities which were later sealed by horizontal growth layers of calcite.

The natural remanence (NRM) of most samples from the axis of each stalagmite is strong but of low coercivity. The average NRM direction of the 33 samples is nevertheless significantly different from the present field direction showing that NRM is not just a recent viscous remagnetization. For the 16 samples stable enough to yield characteristic remanence directions upon stepwise AF demagnetization, the average characteristic direction (declination 23, inclination $-23^{\circ}$ ) is significantly different from the present Earth's field direction (declination $1^{\circ}$, inclination $-35^{\circ}$ ). This and the agreement between characteristic directions of samples of about the same age from the two stalagmites suggest that a paleosecular variation record has been preserved for the past -2500 years.

The minimum magnetic susceptibility axis is not vertical as would be expected along the axis of each stalagmite, if the magnetite grains were in horizontal layers of detritus. Instead, it is the maximum susceptibility axis that tends to be steeply dipping implying that the long (maximum susceptibility) axes of magnetite grains tend to be steeply dipping. We suggest that this is because the magnetite is in flood-emplaced detritus adhering to the sides of cavities that tend to be elongated vertically.

We recommend that susceptibility anisotropy of the samples from the axis of stalagmites be routinely measured by those wishing to recover a paleosecular variation record. They should be encouraged if they find an oblate anisotropy with the minimum axes vertical; although, if anisotropy is high ( $>5 \%$ ), inclination shallowing may have to be corrected for. In contrast, if the maximum susceptibility axes are steeply dipping, flood- emplaced detritus in cavities within the stalagmites may lower the quality of their paleosecular variation record. The latter may be common in tropical areas of high seasonal rain-fall like Java.

\section{Acknowledgments}

The AMS measurements were carried out at Gadjah Mada University in Yogyakarta and were made possible by the kind permission of the late A. Mahfi, to whom we are very grateful. Thanks are also due to La Ode Ngkoimani, Rachman Kurniawan, Yeye Burhanuddin, Zahra, Siti Kasmiati and La Ode Safiuddin for their assistance during various stages of this study. This study was supported financially by the Young Academic Awards (Batch III) from Project URGE and by a research grant from Indonesia Toray Science Foundation to S. B. Project URGE is also thanked for providing financial support to $\mathrm{S}$. B. for a sabbatical exchange program in St. John's and to J. P. $\mathrm{H}$. for a visiting scholar program in Bandung. Further financial support was provided by a grant to J. P. H. from the Natural Sciences and Engineering Research Council of Canada. We also thank Hayao Morinaga for comments that helped improve the earlier version of the manuscript.

\section{References}

1. G. Latham, H. P. Schwarcz, and D. C. Ford, Secular variation of the Earth's magnetic field from 18.5 to $15.0 \mathrm{ka} \mathrm{BP}$, as recorded in a Vancouver Island stalagmite, Can. J. Earth Sci. 24, 1235, 1987.

2. H. Morinaga, H. Inokuchi, and K. Yaskawa, Paleomagnetism of stalagmites (speleothems) in SW Japan. Geophys. J. Int., 96, 519, 1989.

3. G. Latham et al., Secular variation from Mexican stalagmites: their potential and problems. Phys. Earth Planet. Inter. 56, 34, 1989.

4. H. Morinaga, I. Horie, and K. Yaskawa, A geomagnetic reversal recorded in stalagmite collected in Western Japan, J. Geomag. Geoelectr. 44, 661, 1992.

5. G. Latham and D. C. Ford, 1993: The paleomagnetism and rock magnetism of cave and karst deposits, in: D. M. Aïssaoui, D. F. McNeill, and N. F. Hurley (Eds.), Applications of paleomagnetism to sedimentary geology, Society of Sedimentary Geology, Special Publication no. 49, 149, 1993.

6. P. Audra and P. Rochette, Premières traces de glaciation du Pléistocène inférieur dans le massif des Alpes. Datation par paléomagnétisme de remplissages à la grotte Vallier (Vercors, Isère, France). C. R. Acad. Sci. Paris t. 317 Série II, 1403, 1993.

7. B. Lean, A. G. Latham, and J. Shaw, Paleosecular variation from a Vancouver Island stalagmite and comparison with contemporary North American records. J. Geomag. Geoelectr. 47, 71, 1995. 
8. S. Openshaw, A. G. Latham, and J. Shaw, Speleothem paleosecular variation record from China: Their contribution to the coverage of Holocene paleosecular variation data in East Asia, J. Geomag. Geoelectr. 49, 485, 1997.

9. P. Audra, S. Lauritzen, and P. Rochette, Datation de sédiments (U/Th et paléomagnétisme) d'un hyperkarst de Papouasie-Nouvell-Guinée (Montagnes Nakanaï, Nouvelle-Bretagne): Implications dans la connaissance spéléogénétique d'un réseau juvénile (gouffre Muruk), Colloque europeen Karst 99 (Sept. 1015, Avignon, France), Supplément no XXVIII, 43, 1999.

10. R. F. Butler, Paleomagnetism: magnetic domains to geological terranes, Blackwell, Oxford, 319, 1992.

11. J. P. Hodych and S. Bijaksana, Can remanence anisotropy detect paleomagnetic inclination shallowing due to compaction? A case study using Cretaceous deep-sea limestones. J. Geophy. Res. 98, 22429, 1993.

12. S. Bijaksana, and J. P. Hodych, Comparing remanence anisotropy and susceptibility anisotropy as predictors of paleomagnetic inclination shallowing in turbidites from the Scotian Rise. Phys. Chem. Earth 22, 189, 1997.

13. J. P. Hodych, S. Bijaksana, and R. Pätzold, Using magnetic anisotropy to correct for paleomagnetic inclination shallowing in some magnetite-bearing deep-sea turbidites and limestones, Tectonophysics 307, 191, 1999.

14. H. Samodra et al., Geology of the Tulungagung Quadrangle Java, Geological Research and Development Center, Bandung, 1992.

15. Latham, A. G., and H. P. Schwarcz, Carbonate and sulphate precipitates, in: M. Ivanovich, and R. S. Harmon (Eds.), Uranium series disequilibrium: applications to earth, marine, and environmental problems, 2nd ed., Clarendon Press, 423-459, 1992.

16. F. Fadhilah, Crystallographic studies of stalagmites using X-ray diffraction and Rietveld analysis (in Indonesian language), M.Sc. Thesis, Institut Teknologi Bandung, 65, 1999.

17. N. R. Safarina, The use of radicarbon method in determining the absolute ages of stalagmites from Njirak Cave, East Java (in Indonesian language), B.Sc. Thesis, Institut Teknologi Bandung, 54, 1999.

18. S. K. Gupta and H. A. Polach, Radiocarbon dating practices at ANU, Radiocarbon Dating Research, Garran, 172, 1985.

19. G. J. Borradaile and M. Stupavsky, Anisotropy of magnetic susceptibility: measurement schemes, Geophys. Res. Lett. 22, 1957, 1995.

20. McCabe, M. Jackson, and B. B. Ellwood, Magnetic anisotropy in the Trenton limestone: results of a new technique, anisotropy of anhysteretic susceptibility, Geophys. Res. Lett. 12, 333, 1985.

21. V. Jelinek, Characterization of the magnetic fabrics of rocks, Tectonophysics 79, 63, 1993.

22. H. Tarling and F. Hrouda, The magnetic anisotropy of rocks, Chapman \& Hall, London, 217, 1993.

23. J. L., Kirschvink, The least squares line and plane and the analysis of paleomagnetic data, Geophys. J. R. Astron. Soc. 62, 699, 1980.

24. C. Kendall and P. L. Broughton, Origin of fabrics in speleothems composed of columnar calcite crystals, J. Sed. Petrology 48, 519, 1978.

25. G. M. Thompson et al., Uranium series dating of stalagmites from Blanchard Springs Caverns, U.S.A., Geochim. Cosmochim. Acta 39, 1211, 1975.

26. Gondwana Consultants, Secular variation database, IAGA databases version 3.5. 2000. 